\title{
A molecular Approach for Evaluation of Experimental Trials of Anti Schistosomal Vaccination in Murine Models
}

\author{
Samia E. Etewa ${ }^{1}$, Mohamed H. Abdel Hady ${ }^{1}$, Ashraf S. Metwally ${ }^{1}$, \\ Somia H. Abd Allah ${ }^{2}$, Sally M. Shalaby ${ }^{2}$, Amal S. El-Shal ${ }^{2}$, \\ Mahmoud A. EI Shafey ${ }^{3}$, Howayda S.F.Moawad ${ }^{1}$ \\ Medical Parasitology ${ }^{1}$, Biochemistry ${ }^{2}$ and Clinical Pathology ${ }^{3}$ Departments, Faculty of Medicine \\ Zagazig University, Zagazig, Egypt.
}

Corresponding Author Samia Etewa

Mobile: +2012274908 38

E mail:

drsamiaetewa@hotmai l.com

Key words:

Antischistosomal crude vaccine, SEA, SWAP, FCA, modified Kato thick smear, stools PCR and egg DNA
Background and study aim: Current schistosomiasis control strategies are mainly based on chemotherapy, but many researchers believed that the best long term strategy to control schistosomiasis is through immunization with antischistosomiasis vaccines. This study aims at assessment of the efficacy of different potential anti-schistosomal vaccines (as crude soluble egg antigens (SEA), soluble worm antigen preparation (SWAP) and combined SEA \& SWAP) by parasitological and molecular studies in experimental murine models.

Materials and Methods: Sixty male laboratory bred Swiss Albino mice were used and divided into six groups; control normal (G1), control infected by \pm 80 cercariae by S.C. route (G2), Freund's adjuvant (adj.) received then infected (G3), SEA+adj. received then infected (G4), SWAP+ adj. received then infected (G5) and combined (SEA+SWAP) + adj. received then infected (G6). A schedule of sensitization, immunization and schistosomiasis challenge were followed and performed on different mice groups. Mice were euthanized 10 weeks postinfection. Potential vaccine efficacy was investigated by parasitological and molecular studies including egg count/gram stool using modified Kato thick smear, liver egg load, oogram pattern in the liver and stool PCR to detect $S$. mansoni egg DNA in stools of studied mice.

Results: The combined (SEA+SWAP) vaccine caused the highest significant reduction in the fecal egg count followed by SWAP then SEA antigens. On the other hand, the highest percentage reduction in eggs/gram liver tissue was attributed to the combined (SEA+SWAP) followed by SEA then SWAP antigens. Regarding oogram results, the combined (SEA+ SWAP) antigens were more efficient in increasing the number of dead ova with highly significant reduction in the number of mature \& immature ova, followed by SEA then SWAP antigens. The lowest percentage of $S$. mansoni egg DNA detected by PCR in stool samples was encountered with the combined (SEA+ SWAP), followed by SEA then SWAP antigens.

Conclusion:The parasitological and PCRbased assessment studies denoted that the combined (SEA+SWAP) vaccine candidate was the most effective in protection against schistosomiasis challenge. The results of parasitological and molecular studies were nearly similar but the molecular study was more sensitive, definite and accurate.

\section{INTRODUCTION}

Schistosomiasis is a parasitic disease caused by blood flukes of the genus Schistosoma. After malaria and intestinal helminthiasis, schistosomiasis is the third most destructive tropical disease in the world, being a major source of morbidity and mortality for developing countries in Africa, South
America, the Caribbean, the Middle East, and Asia [1]. Mature patent schistosome infections are associated with chronic local inflammatory response to schistosome eggs trapped in host tissues [2]. In the context of schistosomiasis, an effective antischistosome vaccine would contribute greatly to a decrease in morbidity 
associated with schistosomiasis via protective immune responses leading to reduced worm burdens and decreased egg production [3]. Schistosoma parasites secrete \& excrete a number of different antigens into circulation of the host; these antigens are classified according to the stage of development of the parasite into cercarial; adult worm and egg antigens [4]. In order to develop an accurate immunization procedure, many different antigens have been prepared and tested as adult worm and egg antigens [5] and irradiated cercarial antigen [6]. The combination of two vaccines provides augmentation of the protective immunity and reduction of hepatic immunopathology [7].

Microscopic examination of stools remains the gold standard test for diagnosis of schistosoma mansoni infection, either by using a direct fecal smear or after the application of a concentration technique. Schistosoma mansoni eggs are easy to be detected and identified on microscopy owing to their characteristic size and shape with a lateral spine [8].

Kato technique is widely used in field studies and recommended by WHO for diagnosis of intestinal schistosomiasis when the intensity of infection is high, as it could detect the egg load as low as 40 eggs per gram stool [9]. The KatoKatz technique was found to be more sensitive than the formalin ether concentration technique and the wet smear preparation [10].

Polymerase chain reaction (PCR) is a relatively simple technique that can detect a nucleic acid fragment and amplify its sequence, with high sensitivity and specificity [11]. Pontes et al. reported the first use of PCR for the diagnosis of S. mansoni DNA in fecal samples [12].

The current study aims at assessment of the efficacy of different potential antischistosomal vaccines as crude SEA, SWAP and combined SEA \& SWAP by parasitological and molecular (PCR) studies experimentally, in murine models.

\section{MATERIALS AND METHODS}

This experimental study was conducted during the period between February 2013 and May 2014 at the Departments of Medical Parasitology and Biochemistry, Faculty of Medicine, Zagazig University, and Theodor Bilharz Research Institute, Imbaba, Giza, Egypt.

Infective cercariae: According to Liang et al. [13], S. mansoni cercariae (Egyptian strain) were obtained from infected laboratory bred $B$. alexandrina snails which were purchased from Schistosome Biological Supply Center at Theodor Bilharz Research Institute, Imbaba, Giza, Egypt. After exposure to light for at least 4 hours, $S$. mansoni cercariae shed from the snails were used to infect the studied experimental animals ( \pm 80 cercariae/mouse) by subcutaneous injection.

Animals: The current work was carried out on male laboratory-bred, parasite-free Swiss albino mice, about eight weeks's old age and 18-20 grams in weight for each mouse at the beginning of the experiment. Mice were obtained from Schistosome Biological Supply Center at Theodor Bilharz Research Institute (TBRI). The mice were maintained on a standard commercial pelleted diet with free accessible water and in an air-conditioned animal house at $20-22^{\circ} \mathrm{C}$ all over the time of study.

\section{Materials:}

- Schistosomal antigen preparations: Schistosomal crude antigens (SWAP and SEA) were obtained from Schistosome Biological Supply Center at Theodor Bilharz Research Institute (TBRI), Imbaba, Giza, Egypt.

- Adjuvants: Freund's complete adjuvant (FCA) was obtained from Sigma Chemical Co., St Louis, Mo, USA and emulsified in phosphatebuffered saline (PBS) at a ratio of 2:1.

\section{Experimental design: \\ Sample size:}

Sixty albino mice. Mice were divided into six groups (of ten mice each).

\section{Preparation of Antigens:}

SWAP was prepared according to the method of Salih et al. [14], and SEA was prepared according to the method of Boros and Warren [15], the protein content was estimated using Bio-Rad kit (Bio-Rad Laboratories, Hercules, California, USA) [16] and the final concentration was adjusted with PBS to a concentration $50 \mu \mathrm{g} / \mathrm{ml}$ and stored at $-70^{\circ} \mathrm{C}$ until use.

\section{Antigen administration regimens:}

The immunization schedule was performed according to Nabih and Soliman [17]. Each mouse was sensitized with an initial S.C. injection of $200 \mu \mathrm{l}$ of the extracted antigen with a total antigen concentration of $30 \mu \mathrm{g}$ protein. After two weeks, a second S.C. injection of 200 
$\mu l$ of the same antigen was taken and diluted to contain $20 \mu \mathrm{g}$ protein. The antigen was combined with complete Freund's adjuvant at a 1:1 ratio and injected S.C. [18].

\section{Infection of mice:}

Infection of mice was done by subcutaneous injection with about $\pm 80 \mathrm{~S}$. mansoni cercariae/ mouse, suspended in $0.2 \mathrm{ml}$ solution (cercariae in distelled water) 3 weeks after the initial S.C. antigen injection. The suspension was injected into the loose skin of the back of the mouse using an insulin syringe (1 cm length) [19].

\section{Animal groups:}

Group 1: control non infected group.

Group 2: control infected group (infected by \pm $80 \mathrm{~S}$. mansoni cercariae/ mouse by subcutaneous injection).

Group 3: mice were subcutaneously injected with complete Freund's adjuvant (CFA) and then infected by $\pm 80 \mathrm{~S}$. mansoni cercariae (adj. + infected group).

Group 4: mice were subcutaneously injected with soluble egg antigen (SEA) + complete Freund's adjuvant, and then infected (SEA+ adj. + infected group).

Group 5: mice were subcutaneously injected with soluble worm antigen (SWAP) + complete Freund's adjuvant, and then infected (SWAP+ adj. + infected group).

Group 6: mice were subcutaneously injected with SWAP and SEA +complete Freund's adjuvant, and then infected (SEA+ SWAP + adj. + infected group).

\section{Vaccination efficacy assessment:}

Animals were sacrificed by cervical dislocation 10 weeks post infection. Efficacy of the vaccination was assessed by parasitological and molecular studies.

\section{1- Parasitological studies:}

a) Egg count/gram stools using the modified Kato thick smear [20] daily starting from the $7^{\text {th }}$ week post-infection, the average egg count for each mouse and group was calculated and tabulated.

b) Tissue (liver) egg load [21]:

c) Oogram pattern in the liver [22]: for each liver specimen, 100 eggs were microscopically counted \& classified into viable (either immature or mature) and dead.

\section{2- Molecular studies:}

Detection of $S$. mansoni egg DNA in stool samples of studied mice by Polymerase chain reaction "PCR" [12]:

\section{(A) DNA extraction :}

In this study, Extraction of DNA from stool samples was done using QIAamp ${ }^{\circledR}$ DNA stool mini Kit .Cat. No. 51504 (QIAGEN, GmbH, Hilden, Germany).

(B) DNA amplification and PCR reaction: The PCR was done using a forward primer (5'-GAT CTG AAT CCG ACC AAC CG-3') and reverse primer (5'-ATA TTA ACG CCC ACG CTC TC-3') that were designed to amplify the 121-bp tandem repeat DNA sequence of $S$. mansoni. Briefly, for a $25 \mu \mathrm{L}$ final volume of PCR mixture, $5 \mu \mathrm{L}$ of DNA extract was used as template, $12.5 \mu \mathrm{L} 2 \mathrm{X}$ QiagenTag PCR Master Mix $(0.05 \mathrm{u} / \mu \mathrm{L}$ Taq DNA Polymerase, reaction buffer, $4 \mathrm{mM}$ $\mathrm{MgCl}_{2}, 0.4 \mathrm{mM}$ of each dNTPs), $1.5 \mu \mathrm{L}$ of each primer and finally $4.5 \mu \mathrm{L}$ of molecular biology grade water. The amplification reaction was carried out for 35 cycles, with each cycle consisting of a denaturation step at $95{ }^{\circ} \mathrm{C}$ for $40 \mathrm{~s}$, an annealing step at $60^{\circ} \mathrm{C}$ for $30 \mathrm{~s}$ and an extension step at $72{ }^{\circ} \mathrm{C}$ for $1 \mathrm{~min}$. The first cycle had an extended denaturation step for $5 \mathrm{~min}$ and the reaction was ended with an extension step at $72{ }^{\circ} \mathrm{C}$ for $5 \mathrm{~min}$. Amplified PCR products were then analyzed by electrophoresis in $2.5 \%$ agarose gels and detected by UV transillumination after staining with ethidium bromide. Stool samples positive for $S$. mansoni egg DNA showed bands at the level of $121 \mathrm{bp}$ in the DNA ladder, while Stool samples negative for $S$. mansoni egg DNA showed no bands at the level of $121 \mathrm{bp}$ in the DNA ladder [12].

\section{Statistical analysis:}

Data were entered, checked and analyzed using statistical computer program Statistical package for Social Sciences (SPSS version 16 windows). Data were expressed as the mean \pm standard deviation (SD). Comparison between the mean values of different parameters in the studied groups was performed using one way analysis of variance (ANOVA) test, with paired ( $\mathrm{t}$ ) test for comparison between means of two groups. Chi square test was used for comparing between the qualitative data. 


\section{RESULTS}

I- Results of the parasitological studies:

Table (1): The results of Kato technique, Liver egg load and Liver oogram in the different groups

\begin{tabular}{|c|c|c|c|c|c|}
\hline \multirow{2}{*}{ Group } & \multirow{2}{*}{$\begin{array}{c}\text { No. of eggs/g } \\
\text { stool } \\
\end{array}$} & Liver egg load & \multicolumn{3}{|c|}{ Liver oogram } \\
\cline { 4 - 6 } & Mean \pm SD & Mean \pm SD & $\begin{array}{c}\text { Immature } \\
\text { Mean } \pm \text { SD }\end{array}$ & $\begin{array}{c}\text { Mature } \\
\text { Mean } \pm \text { SD }\end{array}$ & $\begin{array}{c}\text { Dead } \\
\text { Mean } \pm \text { SD }\end{array}$ \\
\hline G2 & $361.83 \pm 37.66$ & $1036.17 \pm 72.43$ & $25.3 \pm 3.2$ & $70.5 \pm 1.6$ & $4.2 \pm 0.7$ \\
\hline G3 & $234.83 \pm 27.25$ & $1010.83 \pm 21.25$ & $24.6 \pm 5.6$ & $69.1 \pm 2.9$ & $6.3 \pm 1.6$ \\
\hline G4 & $64 \pm 7.4 * * *$ & $356.83 \pm 36.18^{* * *}$ & $18.1 \pm 2.1 *$ & $35.5 \pm 1.8^{* *}$ & $46.4 \pm 2.3 * * *$ \\
\hline G5 & $56.33 \pm 8.62 * * *$ & $462.83 \pm 41.22^{* * *}$ & $19.6 \pm 1.3 *$ & $44.1 \pm 2.4 * *$ & $36.3 \pm 1.8^{* *}$ \\
\hline G6 & $35.17 \pm 8.2 * * *$ & $108.8 \pm 34.13^{* * *}$ & $6.3 \pm 1.7 * * *$ & $21.3 \pm 2.8^{* * *}$ & $72.4 \pm 3.1 * * *$ \\
\hline
\end{tabular}

*Significant difference from infected control at $\mathrm{p}<0.05$.

**High significant difference from infected control at $\mathbf{p}<0.01$.

***Very high significant difference from infected control at $\mathbf{p}<0.001$.

\section{II- Results of the molecular (PCR) study:}

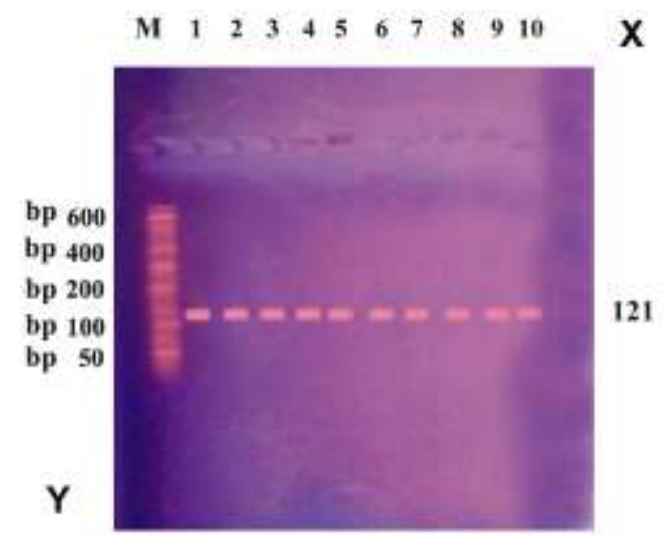

Figure (1): PCR results of (G2) showing that all fecal samples were positive for $S$. mansoni egg DNA (10 bands at $121 \mathrm{bp}$ ).

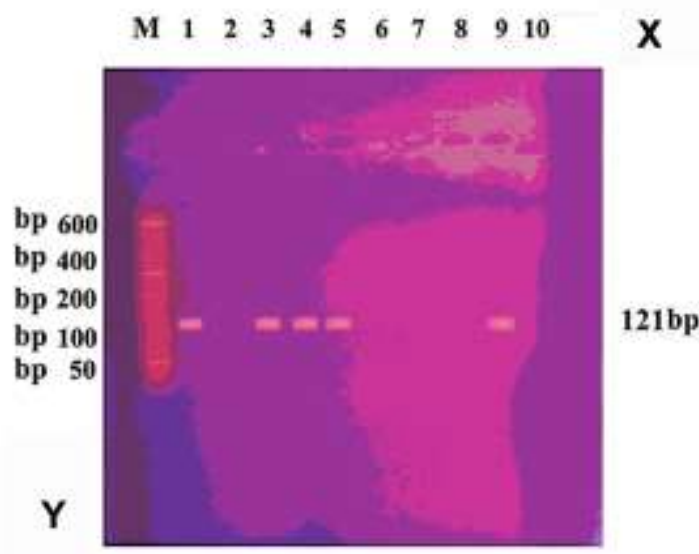

Figure (3): PCR results (G4) showing that five out of ten fecal samples were positive for $S$. mansoni egg DNA (at $121 \mathrm{bp}$ ).
$\begin{array}{lllllllllll}M & 1 & 2 & 3 & 4 & 5 & 6 & 7 & 8 & 9 & 10\end{array}$

$\mathbf{x}$

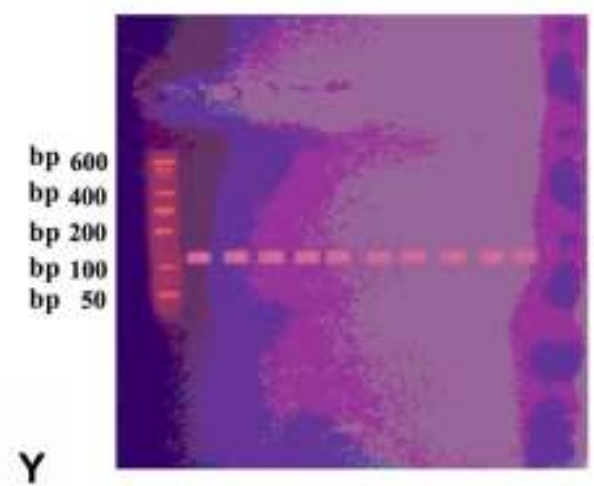

121

Figure (2): PCR results of (G3) showing that all fecal samples were positive for $S$. mansoni egg DNA (10 bands at $121 \mathrm{bp}$ ). 
$\begin{array}{llllllllllll}M & 1 & 2 & 3 & 4 & 5 & 6 & 7 & 8 & 9 & 10\end{array}$

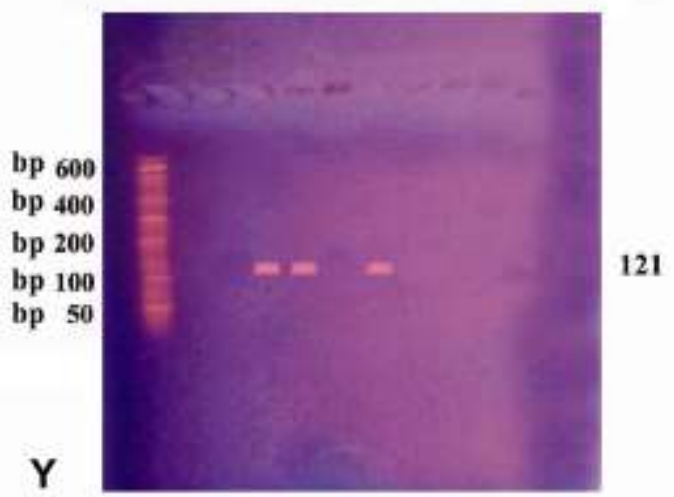

Figure (5): PCR results of (G6) showing that three out of ten fecal samples were positive for S. mansoni egg DNA (at $121 \mathrm{bp})$.

- Axis (Y) represented the number of DNA base pairs in the used DNA marker (ladder).

- Axis (X) represented the stool samples of each group.

- M: molecular weight marker.

- Lanes 1 to 10: represented the PCR results of fecal samples of each group.

Table (2): PCR results of studied control and vaccinated groups

\begin{tabular}{|c|c|c|c|c|c|c|}
\hline Group & $\begin{array}{l}\text { Number } \\
\text { of stools } \\
\text { samples } \\
\end{array}$ & $\begin{array}{c}\text { +ve stools } \\
\text { samples by } \\
\text { PCR } \\
\end{array}$ & $\begin{array}{c}\text {-ve stools } \\
\text { samples by } \\
\text { PCR } \\
\end{array}$ & $\begin{array}{c}\% \text { of +ve } \\
\text { samples }\end{array}$ & Chi sequare $\chi^{2}$ & P-value \\
\hline G1 & 10 & 0 & 10 & $0 \%$ & G2VsG4=6.7 & $0.01 * *$ \\
\hline $\bar{G} 2$ & 10 & 10 & 0 & $100 \%$ & $\underline{\mathrm{G} 2 \mathrm{VsG}_{\mathrm{S}}}=8.5$ & $0.003 * *$ \\
\hline $\bar{G} 3$ & 10 & 10 & 0 & $100 \%$ & $\underline{\mathrm{G} 2 \mathrm{VsG}_{\mathrm{S}}}=10.8$ & $0.001 * *$ \\
\hline G4 & 10 & 5 & 5 & $50 \%$ & G3VsG4 $=6.7$ & $0.01 * *$ \\
\hline G5 & 10 & 4 & 6 & $40 \%$ & $\underline{\text { G3VsG5 }}=8.5$ & $0.003 * *$ \\
\hline G6 & 10 & 3 & 7 & $30 \%$ & $\begin{array}{l}\underline{\mathrm{G} 4 \mathrm{VsG}_{\mathrm{sG}}}=0.2 \\
\underline{\mathrm{G} 4 \mathrm{VsG}_{\mathrm{s}}}=0.8 \\
\mathrm{G} 5 \mathrm{VsG}_{\mathrm{s} 6}=0.2\end{array}$ & $\begin{array}{l}0.6 \\
0.4 \\
0.6\end{array}$ \\
\hline
\end{tabular}

**High significant difference between the groups at $\mathrm{P}$-value $<0.01$

\section{G2VsG4 G2VsG5 $\quad \underline{\text { G2VsG6 }}$ \\ G3VsG6 G3VsG4 $\quad \underline{\text { G3VsG5 }}$}

Insignificant difference between the groups at $\mathrm{P}$-value $>0.05$

$\underline{\text { G4VsG5 }} \underline{\text { G4VsG6 }}$ G5VsG6

Table (3): Comparison between PCR and Kato technique results for evaluation of the efficacy of the different potential antischistosomal vaccines regarding the percentage of positive samples

\begin{tabular}{|c|c|c|c|c|}
\hline & $\begin{array}{c}\text { No. of } \\
\text { samples }\end{array}$ & $\begin{array}{c}\text { No. of +ve } \\
\text { samples }\end{array}$ & $\begin{array}{c}\text { No. of -ve } \\
\text { samples }\end{array}$ & $\begin{array}{c}\text { \% of +ve } \\
\text { samples }\end{array}$ \\
\hline Kato technique & 60 & 26 & 34 & $43 \%$ \\
\hline PCR & 60 & 32 & 28 & $53 \%$ \\
\hline
\end{tabular}

Table (4): The diagnostic value of PCR technique using (Sensitivity \%, Specificity \%, PPV \%, NPV $\%$ and Accuracy \%) as compared to Kato technique

\begin{tabular}{|c|c|c|c|c|}
\hline \multicolumn{5}{|c|}{ PCR } \\
\hline Sensitivity \% & Specificity \% & PPV \% & NPV \% & Accuracy \% \\
\hline $\mathbf{1 0 0 \%}$ & $\mathbf{8 2 \%}$ & $\mathbf{8 1 . 2 5 \%}$ & $\mathbf{1 0 0 \%}$ & $\mathbf{9 0 \%}$ \\
\hline
\end{tabular}


Table (5): Parasitological and molecular results in studied groups

\begin{tabular}{|l|c|c|c|c|c|}
\hline Group Item & G2 & G3 & G4 & G5 & G6 \\
\hline $\begin{array}{l}\text { No. of eggs/g } \\
\text { stool Mean } \pm \text { SD }\end{array}$ & $361.83 \pm 37.66$ & $234.84 \pm 27.25$ & $64 \pm 7.4^{* * *}$ & $56.33 \pm 8.62 * * *$ & $35.17 \pm 8.2^{* * *}$ \\
\hline $\begin{array}{l}\text { Liver egg load } \\
\text { Mean } \pm \text { SD }\end{array}$ & $1036.17 \pm 72.43$ & $1010.83 \pm 21.25$ & $356.83 \pm 36.18^{* * *}$ & $\begin{array}{c}462.83 \pm 41.22^{* * *} \\
*\end{array}$ & $\begin{array}{c}108.8 \pm 34.13 \\
* * *\end{array}$ \\
\hline $\begin{array}{l}\text { Immature } \\
\text { Mean } \pm \text { SD }\end{array}$ & $25.3 \pm 3.2$ & $24.6 \pm 5.6$ & $18.1 \pm 2.1 *$ & $19.6 \pm 1.3 *$ & $6.3 \pm 1.7 * * *$ \\
\hline $\begin{array}{l}\text { Mature } \\
\text { Mean } \pm \text { SD }\end{array}$ & $70.5 \pm 1.6$ & $69.1 \pm 2.9$ & $35.5 \pm 1.8^{* *}$ & $44.1 \pm 2.4^{* *}$ & $21.3 \pm 2.8^{* * *}$ \\
\hline $\begin{array}{l}\text { Dead Mean } \pm \text { SD } \\
\text { \% of +ve stool } \\
\text { samples by } \\
\text { PCR }\end{array}$ & $4.2 \pm 0.7$ & $6.3 \pm 1.6$ & $46.4 \pm 2.3 * * *$ & $36.3 \pm 1.8^{* * *}$ & $72.4 \pm 3.1 * * *$ \\
\hline
\end{tabular}

*Significant difference from infected control at $\mathrm{p}<0.05$.

$* *$ High significant difference from infected control at $\mathrm{p}<0.01$.

$* * *$ Very high significant difference from infected control at $\mathrm{p}<0.001$.

\section{DISCUSSION}

Schistosomiasis is a parasitic disease caused by the digenetic trematodes of the genus Schistosoma members which are commonly known as blood flukes [23]. It is one of the most prevalent parasitic diseases in the world, second to malaria, it is estimated that schistosomiasis causes about 200,000 deaths per year [24].

In this work, vaccination of mice with different schistosomal antigens (SEA, SWAP and combined SEA \& SWAP) showed very high significant results which were supported by previous studies that demonstrated the ability of antigens obtained from different life stages of the parasite to induce protective immune response in mice [25]. On using the crude vaccines, we are putting all the parasite stage components in one preparation because that parasite stage is parasitizing man as one unit by its whole components. So, the current study aimed to evaluate the efficacy of the potential antischistosomal vaccines using crude preparation of (SEA, SWAP and combined SEA+SWAP) by parasitological and molecular methods.

A significant reduction in the number of $S$. mansoni eggs in stool samples was detected 10 weeks post infection in comparison to the control infected group. The highest percentage reduction "90.3 \%" was encountered with the combined SEA \& SWAP-vaccinated group. On the other hand, there was insignificant reduction in ova count in (Freund's adjuvant + infected) group when compared to the control infected group.

These results were in agreement with those reported by Gundersen et al. [26] who found a positive correlation between the number of eggs per gram stools (using Kato technique) and the schistosomal antigen level.

The present results were in agreement with those of Ismail [27] who used also crude antigens and reported very high significant reduction in fecal egg count in mice vaccinated by adjuvant and combined schistosomal antigens (CAP + SWAP + SEA). The current results were in accordance with Etewa et al. [28], who found that a significant reduction in the mean egg counts/g stools was recorded by Kato technique in combined (CAP+SEA+SWAP) - vaccinated group, as compared to control infected group. On the other hand, a statistically insignificant reduction in the mean egg counts/g stools was recorded in the adjuvant- received group as compared to control infected group $(\mathrm{P}>0.05)$.

The present work cleared that the most effective antigen with very high significant reduction in liver egg load (the mean egg count/gram liver) was the combined vaccine + FCA, followed by SEA + FCA then SWAP + FCA. On the other hand, insignificant reduction was detected in the FCA- received group as compared to control infected group. These results nearly coincided with those of Etewa et al. [29] who detected that 
the most effective antigen with significant reduction in tissue (liver) egg load was the combined (CAP, SWAP \& SEA) + Freund's adjuvant with $93.67 \%$ percentage reduction as compared to control infected group in spite of using an extra antigen (CAP). On the other hand, the current results were not near to those of Romeih et al. [30] who noted that there was a significant reduction $(41.53 \%)$ in the mean number of eggs/g liver of the multivalent DNAvaccinated mice group, as compared to the control group. This may be attributed to the difference in antigen preparation. They also added that a significant reduction $(29.90 \%)$ in the fecundity of female worms was observed after vaccination, denoting that the multivalent DNA vaccine permitted a better growth of mice and reduced the worm burden, egg number and worm fecundity.

In agreement, Fallon and Dunne [31] \& Ismail [27] reported that administration of individual or combined schistosomal antigens led to significant reduction in worm burden with subsequent decrease in the number of deposited eggs. Besides, Teixeira de Melo et al. [25] explained that immunization of mice with adult worm tegument (Smteg) together with Freund's adjuvant induced a Th1 type of immune response associated with a significant reduction in eggs trapped in the liver by $65 \%$.

On the other hand, results of the present study were higher than that of El-Ahwany et al. [32] who used SEA without Freund's adj. and Rezende et al. [33] in SWAP vaccinated group; they reported a percentage reduction in the liver tissue egg load of $42.8 \%$ and $8.4 \%$, respectively.

This contrary may be explained by the higher protective effect of the combined (cocktail) antigens together with the augmenting role of Freund's adjuvant in nonspecific induction of the immune system.

In this work, the most effective antigen resulting in remarkable oogram changes with highly significant reduction in immature \& mature ova and highly significant increase in dead ova was the combined vaccine + Freund's, followed by SEA + Freund's then SWAP + Freund's. On the other hand, insignificant oogram changes were detected in the adjuvant + infected group, as compared to control infected group. The present findings were partially agreed with those of Ismail [27] and Etewa et al. [29] who reported marked oogram changes in the vaccinated groups with highly significant reduction in immature and mature ova together with a highly significant increase in dead ova in combined vaccine (CAP + SEA + SWAP $)$ + Freund's, followed by SEA + Freund's, then SWAP + Freund's.

In the present study, it was noticed that the decrease in Schistosoma mansoni egg count in stools of vaccinated groups (G4, G5 and G6) was directly proportional to the decrease in liver egg load, mature and immature egg numbers, while it was inversely proportional to the number of dead eggs in the oogram pattern.

These results were similar to that of Ismail [27] and Etewa et al. [29] who found marked reduction in fecal egg count, liver egg load, immature and mature eggs number in oogram and marked increase in dead ova in the vaccinated groups which demonstrated positive efficacy of the tested antigens.

Techniques for identifying circulating $S$. mansoni DNA have been widely used and such methods have demonstrated that it is possible to detect infections as early as one day after parasite exposure [34].

PCR-based diagnosis has been shown to be highly sensitive and specific and should therefore be considered as alternative methods for the diagnosis of S. mansoni infections [35].

The present study revealed that the combined (SWAP + SEA) potential vaccine was the most protective regarding detection of $S$. mansoni egg DNA in stools of $S$. mansoni - challenged mice with $70 \%$ success, followed by SWAP then SEA antigens with $50 \%$ and $40 \%$ success, respectively, as compared to control infected group. On the other hand, the adjuvant alone (G3) exhibited no protection and all fecal samples were positive for egg DNA by PCR.

Considering that the Kato technique is the gold standard test, we found that the PCR sensitivity was $100 \%$, specificity was $82 \%$, PPV was $81.25 \%$ and NPV was $100 \%$. So, PCR was more accurate in evaluating the tested antigens as potential vaccines.

The obtained results are nearly in agreement with Pontes et al. [36] who compared between Kato technique and PCR for diagnosis of $S$. mansoni infection and evaluation of the efficacy of Praziquantel in treatment of infection. They found that the PCR technique showed a sensitivity of $96.7 \%$, a specificity of $88 \%$, PPV 
was $78.4 \%$ and NPV was $98.3 \%$, using the parasitological examination as the reference test.

Moreover, our results were near to those of Gomes et al., who compared between the Kato technique and PCR for diagnosis of $S$. mansoni in stool samples. They studied 67 cases and found that Kato technique detected infection in $42 \%$ of samples while, PCR detected infection in $61 \%$ of samples. However, they reported that PCR sensitivity was $92.9 \%$ and PCR specificity was $61.5 \%$ [37].

The current results were also in agreement with those of Oliveira et al., who studied fecal samples using 2 PCR assays utilizing distinct primer pairs. One of the primer pairs was targeted to a highly repeated 121-base pair sequence of $S$. mansoni, and the other was targeted to Schistosoma 28S rDNA. The results obtained with stool samples from individuals with schistosomiasis showed a high sensitivity for PCR as S. mansoni DNA was detected in $91 \%$ of the samples analyzed [38].

The obtained results are also supported by de Carvalho et al., who reported that the assessment of a single faecal sample by PCR detected more cases of infection than the analysis of one sample with two slides using the Kato-Katz technique, suggesting that PCR can be a useful diagnostic tool, particularly in areas with low endemicity. They found that the PCR sensitivity was $93.8 \%$, specificity was $70 \%$, PPV was $100 \%$ and NPV was $99.3 \%$ [39].

The present findings partially differ from those of Carneiro et al., who analysed and compared the results from a conventional PCR-based method with results from serological (ELISA) and parasitological tests. S. mansoni was detected by the KK technique in $33.9 \%$ of cases. In contrast, the PCR-based method was able to detect $S$. mansoni in $68.4 \%$ of cases i.e. more than two-fold increase in sensitivity. However, PCR failed to detect DNA in six samples that were confirmed to be positive by parasitological examination and ELISA [35]. Pontes et al. [36] reported that missed cases after PCR were certainly misdiagnosed by the DNA amplification assay due to many factors such as: inhibition of the amplification reaction by fecal compounds and/or DNA degradation during transportation from the field, variation in egg output and uneven distribution in feces.

\section{CONCLUSION}

On using combined antigens as a potential vaccine, more stimulation of the immune system against different antigenic components will occur, thus increasing the vaccine efficacy. This suggests that development of a multivalent (cocktail of antigens) vaccine may be the way forward, while the molecular method (stool PCR) for vaccine evaluation was more sensitive, accurate and definite.

Funding: None.

Conflicts of interest: The authors declare that there is no conflict of interest.

Ethical approval: All procedures related to animal experimentation in the present study met the International Guiding Principles for Biomedical Research Involving Animals as issued by the International Organizations of Medical Sciences and approved by the ethics committee of the Faculty of Medicine, Zagazig University.

\section{REFERENCES}

1- World Health Organization 2010 Schistosomiasis. Available at http://www.who.int/mediacentre/ factsheets/fs115/en/. Accessed Oct 5, 2010.

2- Gryseels B, Polman K, Clerinx J, Kestens L. Human schistosomiasis. Lancet 2006; 368:110618.

3- McManus DP, Loukas A. Current status of vaccines for schistosomiasis. Clin Microbiol Rev 2008; 21: 225-42.

4- Van Lieshout L, Polderman AM, Deelder AM. Immunodiagnosis of schistosomiasis by determination of the circulating antigens CAA and CCA, in particular in individuals with recent or light infections. Acta Trop 2000; 77: 6980 .

5- Montesano M, Danie 1A, Colley G, George L, Freeman JR, Evan SW. Neonatal Exposure to idiotype induces S.mansoni egg antigen-specific cellular and humoral immune responses. $J$ Immunol 1999; 163: 898-905.

6- Zhang Y, Taylor MG, McCrossan MV, Bickle QD. Molecular cloning and characterization of a novel $S$. japonicum irradiated vaccine-specific antigen Sj 14-3-3. Mol Biochem Parasitol 1999; 103: 25-34.

7- Khalifa RMA, Elnadi NA, Omran EK, AbdelTawab RA. Immunological response and the probability of production of vaccine for schistosome parasites. Egypt J Med Sci 2011; 32(2): 547-70. 
8- Kongs A, Marks G, Verle P, Van der Stuyft P. The unreliability of the Kato-Katz technique limits its usefulness for evaluating S. mansoni infections. Tropical Medicine and International Health 2001; 6 (3): 163-169.

9- Utzinger J, N'Goran EK, N'Dri A, Lengeler C, Tanner M. Efficacy of praziquantel against Schistosoma mansoni with particular consideration for intensity of infection. Trop Med Int Health 2000; 5: 771-8.

10- Idris MA, Al-Jabri AM. Usefulness of KatoKatz and trichrome staining as diagnostic methods for parasitic infections in clinical laboratories. J Sci Res Med Sci 2001; 3(2): 6568.

11- Louie M, Louie L, Simor A. The role of DNA amplification technology in the diagnosis of infectious diseases. CMAJ 2000; 163(3): 301309.

12- Pontes LA, Dias-Neto E, Rabello A. Detection by polymerase chain reaction of Schistosoma mansoni DNA in human serum and feces. Am J Trop Med Hyg 2002; 66: 157-62.

13- Liang YS, John I, Bruce JI, David AB. Laboratory cultivation of schistosome vector snails and maintenance of schistosome life cycle. Proc First Sine Am Symp 1987; 1:34.

14- Salih SY, Bartlett A, Voller A. Detection of antibodies by enzyme immunoassay in human Schistosoma mansoni infection a clinical chemotherapeutic study. J Trop Parasitol 1978; 29: 409-12.

15- Boros DL, Warren KS. Delayed hypersensitivity type 11l: granuloma formation and dermal reaction induced and elicited by a soluble factor isolated from Schistosoma mansoni eggs. J Exp Med 1970; 132:488-507.

16- Bradford MM. A rapid and sensitive method for the quantitation of microgram quantities of protein utilizing the principle of protein-dye binding. Anal Biochem 1976; 72: 248-54.

17- Nabih I, Soliman AM. Studies on fresh water snails, specific intermediate host for schistosomiasis. II. Isolation of total protein from native and irradiated snails. Cell Mol Biol 1986; 32: 315-317.

18- Smithers SR, Hackett F, Ali OP, Simpson AJG. Protective immunization of mice against schistosoma mansoni with purified adult worm surface membranes. Parasite Immuno 1989; 111:301-318.

19- Peters AP, Warren KS. A rapid method of infecting mice and other laboratory animals with Schistosoma mansoni subcutaneous injection. $J$ Parasitol 1969; 55: 558- 63.

20- Martin LK, Beaver PC. Evaluation of kato thick-smear technique for quantitative diagnosis of helminth infection. Am J Trop Med Hyg 1968; 17: 382.
21- Cheever AW. Postmortem study of schistosomiasis manosni in man. Am J Trop Med Hyg 1968; 17:38-64.

22- Pellegrino J, Faria J. The oogram method for the screening of drugs in schistosomiasis mansoni. Am J Trop Med Hyg 1965; 14: 363-69.

23- Barakat RMR. Epidemiology of Schistosomiasis in Egypt: Travel through Time: Review. J. Adv Res 2013; 4:425-432.

24- Mahfouz A, Mahana N, Rabee I, El Amir A. Evaluation of Different Immunological Techniques for Diagnosis of Schistosomiasis haematobium in Egypt. Life Science Journal 2011; 8(4):858-67.

25- Teixeira de Melo T, Michel de Araujo J, DoValle Durães F, Caliari MV, Oliveira SC, Coelho PM, Fonseca CT. Immunization with newly transformed Schistosoma mansoni schistosomula tegument elicits tegument damage, reduction in egg and parasite burden. Parasite Immunol 2010; 32(11-12): 74959.

26- Gundersen SG, Hagensen I, Jonassen TO, Figenschau KJ, de Jonge NDeelder AM. Magnetic bead antigen capure enzyme linked immunoassay in microtitre trays for rapid detection of schistosomal circulating anodic antigen. J Immunol Meth 1992; 148: 1-10.

27- Ismail OA. Study of the efficacy of adult worm, cercarial and egg antigens in protection against experimental intestinal schistosomiasis. MD.Thesis. Faculty of Medicine, Suez Canal University 2005.

28- Etewa SE, Abd El-Aal NF, Abd El Rahman SA, Abd El Bary EH, El Shafei M. Studies on the role of tumour necrosis factor -alpha (TNF- $\alpha)$ in hepatocytes induced apoptosis in vaccinated, Schistosoma mansoni challenged mice. J Egypt Soc Parasitol 2015; 45(1):47-60.

29- Etewa SE, Abd El-Aal NF, Abd El Rahman SA, El Shafei M. Parasitological evaluation of potential candidate vaccines in Schistosoma mansoni-infected mice. JPVB 2014a; 6(2): 2330.

30- Romeih MH, Hassan HM, Shousha TS, Saber MA. Immunization against Egyptian Schistosoma mansoni infection by multivalent DNA vaccine. Acta Biochim Biophys Sin (Shanghai) 2008; 40(4):327-38.

31- Fallon PG, Dunne DW. Tolarization of mice to Schistosoma mansoni egg antigens causes elevated type 1 and diminished type 2 cytokine responses and increased mortality in acute infection. J Immunol 1999; 162:4122-32.

32- El-Ahwany E, Bauiomy IR, Nagy F, Zalat R, Mahmoud O, Zada ST. Regulatory cell responses to immunization with a soluble egg antigen in Schistosoma mansoni infected mice. Korean $J$ Parasitol 2012; 50(1):29-35. 
33- Rezende CMF, Silva MR, Santos IGD, Silva GAB, Gomesa D A, Goesa AM. Immunization with rP22 induces protective immunity against Schistosoma mansoni: Effects on granuloma down-modulation and cytokine production. Immunology Letters 2011; 141 : 123-33.

34- Gentile R, Gonçalves MML, Neto SFC, Costa MM, Peralta RHS, Peralta JM. Evaluation of immunological, parasitological and molecular methods for the diagnosis of Schistosoma mansoni infection before and after chemotherapy treatment with praziquantel in experimentally infected Nectomys squamipes. Vet Parasitol 2011; 180: 243-49.

35- Carneiro TR, Peralta RH, Pinheiro MC, de Oliveira SM, Peralta JM, Bezerra FS. A conventional polymerase chain reaction-based method for the diagnosis of human schistosomiasis in stool samples from individuals in a low-endemicity area. MemInst Oswaldo Cruz Rio de Janeiro 2013; 108(8):1037-44.

36- Pontes LA, Oliveira MC, Katz N, Dias-Neto E, Rabello A. Comparison of a polymerase chain reaction and the Kato-Katz technique for diagnosing infection with Schistosoma mansoni. Am J Trop Med Hyg 2003; 68: 652-56.
37- Gomes LI, Marques LHS, Enk M J, Coelho P M Z, Rabello A. Further evaluation of an updated PCR assay for the detection of Schistosoma mansoni DNA in human stools samples. Mem Inst Oswaldo Cruz 2009; 104: 1194-96.

38- Oliveira LMA, Santos HLC, Gonçalves MML, Barreto MGM, Peralta JM. Evaluation of polymerase chain reaction as an additional tool for the diagnosis of low-intensity Schistosoma mansoni infection. Diagn Microbiol Infect Dis 2010; 68: 416-21.

39- de Carvalho GC, Marques LH, Gomes LI, Rabello A, Ribeiro LC, ScopelKK Tibiriçá SH, Coimbra ES, Abramo C. Polymerase chain reaction for the evaluation of Schistosoma mansoni infection in two low endemicity areas of Minas Gerais, Brazil .Mem Inst Oswaldo Cruz Rio de Janeiro 2012; 107(7): 899-902.

Peer reviewer: Tarik Zaher; Professor of Tropical Medicine, Faculty of Medicine, Zagazig University, Egypt.

Editor: Mohamed H Emara; Assistant Professor of Tropical Medicine, Faculty of Medicine, Zagazig University, Egypt. 